\title{
Spatial distribution of dinoflagellate resting cysts in Yellow Sea surface sediments
}

\author{
Choul-Hee Hwang ${ }^{1}$, Keun-Yong Kim ${ }^{2}$, Yoon Lee ${ }^{3}$ and Chang-Hoon Kim ${ }^{2, *}$ \\ ${ }^{1}$ Fish Research Team, Marine Eco-Technology Institute Co., Ltd., Busan 608-830, Korea \\ ${ }^{2}$ Department of Marine Bio-materials and Aquaculture, Pukyong National University, Busan 608-737, Korea \\ ${ }^{3}$ West Sea Fisheries Research Institute, National Fisheries Research \& Development Institute, Incheon 400-420, Korea
}

\begin{abstract}
Yellow Sea surface sediment samples collected on October 15-31, 2003 were analyzed using the palynological process to investigate the spatial distribution of dinoflagellate resting cysts. The sampling areas comprised four latitudinal transects, the northernmost of which was located off the Shandong Peninsula, China and the southernmost off Jeju Island, Korea. Each transect line was composed of six to nine stations, spanning the distance between the Chinese and Korean coasts. Twenty-five different types of dinoflagellate cysts were identified. Gonyaulax scrippsae, Alexandrium spp. (ellipsoidal type), and G. spinifera were the most dominant at all stations surveyed. Dinoflagellate cysts belonging to the Gonyaulacales comprised over $50 \%$ of all cysts collected. The latitudinal distribution trend showed that cyst concentrations along the two middle transects were much higher than those along the two northern and southern transects. Cyst concentrations in the offshore central areas reached their highest values within each transect and gradually decreased toward the Chinese and Korean coasts. Overall, cyst concentrations were markedly elevated in the offshore central Yellow Sea areas and gradually decreased outward in all four directions. This concentric cyst distribution pattern was consistent with the hydrographic features of the Yellow Sea, such as circular current systems, sedimentary properties, and water depth.
\end{abstract}

Key Words: dinoflagellate; resting cyst; spatial distribution; Yellow Sea

\section{INTRODUCTION}

A number of dinoflagellates cause harmful algal blooms (HABs) in the marine ecosystem. Some have complex life cycles, including the benthic cyst stage. Dinoflagellate resting cysts play important ecological roles in bloom initiation and termination, as agents of survival and dispersal, in genetic recombination, and as a potential toxin source to benthic mollusks. Thus, geographical cyst mapping pinpoints the presence of "seed populations" for bloom initiation sites and traces dispersal paths that suggest the potential for future HAB outbreaks
(Pfiester and Anderson 1987).

The Yellow Sea forms one of the largest epicontinental shelves. It is partially enclosed by the Chinese and Korean coasts and borders on the Bohai and East China Seas. The Yellow Sea rests in a tectonically stable trough that was submerged during the postglacial sea-level rise, with an average water depth of $55 \mathrm{~m}$ (Jin and Chough 1998, Uehara and Saito 2003).

Yellow Sea sediments consist of sand, muddy sand, sandy mud, and mud, in order of the percentage of mud (c) This is an Open Access article distributed under the terms of the Creative Commons Attribution Non-Commercial License (http://creativecommons.org/licenses/by-nc/3.0/) which permits unrestricted non-commercial use, distribution, and reproduction in any medium, provided the original work is properly cited.
Received 15 January 2011, Accepted 26 February 2011

*Corresponding Author

E-mail: chkpknu@hanmail.net

Tel: +82-51-629-5917 Fax: +82-51-629-5908 
or sand. The suspended fine-grained materials near shore move along the Yellow Sea circular current system route and are transported to and accumulate on the seafloor at the eddy center of the Yellow Sea to form muddy sediments. As a result, the largest mud-rich sediment patch developed in the central part of the Yellow Sea, and muddy sand and sand are distributed in an outward manner (Park and Khim 1992, Uehara and Saito 2003, Shi et al. 2004).

Several dinoflagellate cyst distribution studies have been conducted in the East China and / or Yellow Seas (Qi et al. 1996, Cho and Matsuoka 2001, Cho et al. 2001). However, the previous studies only covered part of the Yellow Sea; thus, they are insufficient for interpreting cyst distributions over the entire Yellow Sea. In this study, we investigated the spatial distribution and species composition of dinoflagellate cysts in surface sediment samples, which covered nearly the entire Yellow Sea continental shelf. The cyst distribution was compared to hydrographic and sedimentary properties of the Yellow Sea to understand the origin, dispersal paths, and depositional sites of the cysts.

\section{MATERIALS AND METHODS}

A cruise was conducted around the Yellow Sea for this study (Table 1) on October 15-31, 2003 using the $R / V$ Tamgu 8 of the West Sea Fisheries Research Institute, National Fisheries Research and Development Institute (NFRDI), Korea. Sediment samples were collected with a Van Veen grab sampler from 33 stations on four transect lines that ran latitudinally between the Chinese and Korean coasts. The northernmost transect was located off the Shandong Peninsula, China, and the southernmost transect was located off Jeju Island, Korea, in a longitudinal direction. The top-surface grab sample fractions (0-3 $\mathrm{cm}$ ) were carefully collected on board the ship and stored at $4^{\circ} \mathrm{C}$ in the dark until analysis.

After calculating water content, sediment samples were processed according to Matsuoka and Fukuyo (2000). Briefly, they were treated with $10 \% \mathrm{HCl}$ and $47 \%$ HF to dissolve calcium carbonate and silicate materials, respectively. They were then rinsed with distilled water and sonicated using an Ultrasonic Cleaner 5210 (Branson Ultrasonics, Danbury, CT, USA) for $30 \mathrm{~s}$. After straining through $120 \mu \mathrm{m}$ and $20 \mu \mathrm{m}$ mesh sieves, the refined sediments remaining on the $20-\mu \mathrm{m}$ sieve were transferred to a $15 \mathrm{~mL}$ tube and suspended in $10 \mathrm{~mL}$ of distilled water. A $1 \mathrm{~mL}$ aliquot of each sample was observed under an inverted light microscope (Axiovert 200; Zeiss, Oberkochen, Germany). Cyst concentrations were calculated as the number of cysts per gram of dry weight.

Identification followed Matsuoka and Fukuyo (2000).

Table 1. Latitude, longitude, and water depth of each station investigated in the Yellow Sea

\begin{tabular}{|c|c|c|c|}
\hline \multicolumn{2}{|c|}{ Station } & \multirow{2}{*}{$\begin{array}{c}\text { GPS coordinate } \\
36^{\circ} 55^{\prime} 50^{\prime \prime} 123^{\circ} 07^{\prime} 70^{\prime \prime}\end{array}$} & \multirow{2}{*}{$\begin{array}{c}\text { Water depth (m) } \\
47\end{array}$} \\
\hline Transect A & $\mathrm{A} 1$ & & \\
\hline & A2 & $36^{\circ} 55^{\prime} 50^{\prime \prime} 123^{\circ} 37^{\prime} 70^{\prime \prime}$ & 75 \\
\hline & A3 & $36^{\circ} 55^{\prime} 50^{\prime \prime} 124^{\circ} 07^{\prime} 70^{\prime \prime}$ & 77 \\
\hline & A4 & $36^{\circ} 55^{\prime} 50^{\prime \prime} 124^{\circ} 37^{\prime} 70^{\prime \prime}$ & 78 \\
\hline & A5 & $36^{\circ} 55^{\prime} 50^{\prime \prime} 125^{\circ} 07^{\prime} 70^{\prime \prime}$ & 50 \\
\hline & A6 & $36^{\circ} 55^{\prime} 50^{\prime \prime} 125^{\circ} 20^{\prime} 70^{\prime \prime}$ & 55 \\
\hline \multirow[t]{9}{*}{ Transect B } & B1 & $35^{\circ} 51^{\prime} 30^{\prime \prime} 121^{\circ} 32^{\prime} 00^{\prime \prime}$ & 40 \\
\hline & B2 & $35^{\circ} 51^{\prime} 30^{\prime \prime} 122^{\circ} 02^{\prime} 00^{\prime \prime}$ & 46 \\
\hline & B3 & $35^{\circ} 51^{\prime} 30^{\prime \prime} 122^{\circ} 32^{\prime} 00^{\prime \prime}$ & 61 \\
\hline & $\mathrm{B} 4$ & $35^{\circ} 51^{\prime} 30^{\prime \prime} 123^{\circ} 02^{\prime} 00^{\prime \prime}$ & 70 \\
\hline & B5 & $35^{\circ} 51^{\prime} 30^{\prime \prime} 123^{\circ} 32^{\prime} 00^{\prime \prime}$ & 73 \\
\hline & B6 & $35^{\circ} 51^{\prime} 30^{\prime \prime} 124^{\circ} 02^{\prime} 00^{\prime \prime}$ & 77 \\
\hline & B7 & $35^{\circ} 51^{\prime} 30^{\prime \prime} 124^{\circ} 32^{\prime} 00^{\prime \prime}$ & 85 \\
\hline & B8 & $35^{\circ} 51^{\prime} 30^{\prime \prime} 125^{\circ} 02^{\prime} 00^{\prime \prime}$ & 77 \\
\hline & B9 & $35^{\circ} 51^{\prime} 30^{\prime \prime} 125^{\circ} 32^{\prime} 00^{\prime \prime}$ & 71 \\
\hline \multirow[t]{9}{*}{ Transect C } & $\mathrm{C} 1$ & $34^{\circ} 43^{\prime} 00^{\prime \prime} 121^{\circ} 02^{\prime} 00^{\prime \prime}$ & 25 \\
\hline & $\mathrm{C} 2$ & $34^{\circ} 43^{\prime} 00^{\prime \prime} 121^{\circ} 32^{\prime} 00^{\prime \prime}$ & 43 \\
\hline & C3 & $34^{\circ} 43^{\prime} 00^{\prime \prime} 122^{\circ} 02^{\prime} 00^{\prime \prime}$ & 50 \\
\hline & $\mathrm{C} 4$ & $34^{\circ} 43^{\prime} 00^{\prime \prime} 122^{\circ} 32^{\prime} 00^{\prime \prime}$ & 66 \\
\hline & C5 & $34^{\circ} 43^{\prime} 00^{\prime \prime} 123^{\circ} 02^{\prime} 00^{\prime \prime}$ & 75 \\
\hline & C6 & $34^{\circ} 43^{\prime} 00^{\prime \prime} 123^{\circ} 32^{\prime} 00^{\prime \prime}$ & 78 \\
\hline & $\mathrm{C} 7$ & $34^{\circ} 43^{\prime} 00^{\prime \prime} 124^{\circ} 02^{\prime} 00^{\prime \prime}$ & 80 \\
\hline & $\mathrm{C} 8$ & $34^{\circ} 43^{\prime} 00^{\prime \prime} 124^{\circ} 32^{\prime} 00^{\prime \prime}$ & 93 \\
\hline & C9 & $34^{\circ} 43^{\prime} 00^{\prime \prime} 124^{\circ} 49^{\prime} 00^{\prime \prime}$ & 87 \\
\hline \multirow[t]{9}{*}{ Transect D } & D1 & $33^{\circ} 34^{\prime} 70^{\prime \prime} 121^{\circ} 32^{\prime} 00^{\prime \prime}$ & 20 \\
\hline & D2 & $33^{\circ} 34^{\prime} 70^{\prime \prime} 122^{\circ} 02^{\prime} 00^{\prime \prime}$ & 26 \\
\hline & D3 & $33^{\circ} 34^{\prime} 70^{\prime \prime} 122^{\circ} 32^{\prime} 00^{\prime \prime}$ & 41 \\
\hline & D4 & $33^{\circ} 34^{\prime} 70^{\prime \prime} 123^{\circ} 02^{\prime} 00^{\prime \prime}$ & 49 \\
\hline & D5 & $33^{\circ} 34^{\prime} 70^{\prime \prime} 123^{\circ} 32^{\prime} 00^{\prime \prime}$ & 67 \\
\hline & D6 & $33^{\circ} 34^{\prime} 70^{\prime \prime} 124^{\circ} 02^{\prime} 00^{\prime \prime}$ & 73 \\
\hline & D7 & $33^{\circ} 34^{\prime} 70^{\prime \prime} 124^{\circ} 32^{\prime} 00^{\prime \prime}$ & 84 \\
\hline & D8 & $33^{\circ} 34^{\prime} 70^{\prime \prime} 125^{\circ} 02^{\prime} 00^{\prime \prime}$ & 85 \\
\hline & D9 & $33^{\circ} 34^{\prime} 70^{\prime \prime} 125^{\circ} 32^{\prime} 00^{\prime \prime}$ & 90 \\
\hline
\end{tabular}


Resting cysts were called cysts for the sake of brevity, and only living cysts were counted.

\section{RESULTS}

Twenty-five different types of dinoflagellate cysts were identified in Yellow Sea surface sediments, representing 14 genera and belonging to the Gonyaulacales (10 species), Peridiniales (10 species), and Gymnodiniales (4 species) (Tables 2-5). The most common species were Gonyaulax scrippsae, Alexandrium spp. (ellipsoidal type), and G. spinifera, all of which belong to the Gonyaulacales. Concentrations of Protoceratium reticulatum, G. verior, and Scrippsiella spp. were also relatively high. Other species of cysts occurred in relatively low numbers.

Transect A was the northernmost transect located off the Shandong Peninsula, and 23 types of cysts were iden- tified (Table 2, Fig. 1). Cyst concentrations were significantly higher at station A3 (5,396 cells g $^{-1}$ dry weight) in the central area than at the stations in the marginal areas of the Shandong Peninsula and Korea. Alexandrium spp. (ellipsoidal type, 96-2,153 cells $\mathrm{g}^{-1}$ ) were the most abundant, followed by Gonyaulax scrippsae (9-844 cells g-1), $G$. spinifera (6-489 cells g-1), G. verior (18-319 cells g-1), Protoceratium reticulatum (6-443 cells $\mathrm{g}^{-1}$ ), and Pheopolykrikos hartmannii (31-446 cells g-1).

We recorded 24 types of cysts from transect B located south of transect A (Table 3, Fig. 1). Total concentrations were markedly high in the central areas (stations B3-B6, 10,552-20,828 cells $\mathrm{g}^{-1}$ ) but decreased sharply towards the coastal areas of China and Korea. Station B4 in the central region had the highest density of cysts $\left(20,828\right.$ cells $\left.\mathrm{g}^{-1}\right)$ among all sediment samples analyzed. The major species identified were Gonyaulax scrippsae (10-6,985 cells $\left.\mathrm{g}^{-1}\right)$, G. spinifera (5-4,929 cells g-1 $)$, Alexandrium spp. (ellipsoi-

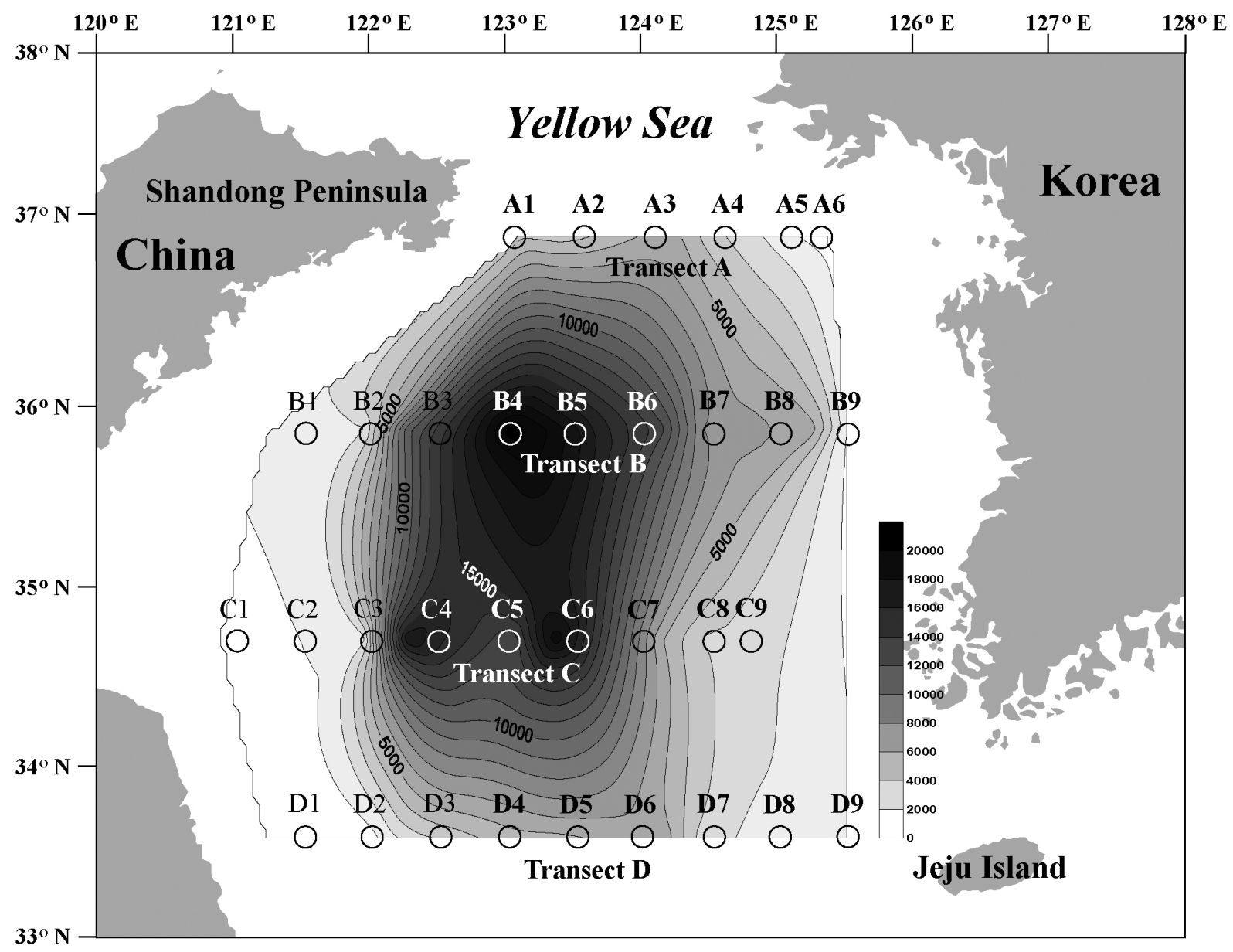

Fig. 1. A contour map of the spatial distribution of all dinoflagellate cysts found in Yellow Sea surface sediments. Contour lines are increments of 1,000 cells $\mathrm{g}^{-1}$ dry weight. 
Table 2. Distribution of dinoflagellate cysts (cells $\mathrm{g}^{-1}$ dry weight) at transect A in Yellow Sea surface sediments

\begin{tabular}{|c|c|c|c|c|c|c|}
\hline \multirow{2}{*}{ Species } & \multicolumn{6}{|c|}{ Stations } \\
\hline & A1 & A2 & A3 & A4 & A5 & A6 \\
\hline \multicolumn{7}{|l|}{ Gonyaulacales } \\
\hline Alexandrium spp. (ellipsoidal) & 578 & 716 & 2,153 & 1,730 & 96 & 344 \\
\hline Alexandrium spp. (spherical) & 191 & 283 & 167 & 187 & 28 & 50 \\
\hline Gonyaulax scrippsae & 404 & 407 & 844 & 219 & 9 & 33 \\
\hline Gonyaulax spinifera & 431 & 318 & 489 & 160 & 6 & 40 \\
\hline Gonyaulax verior & 117 & 142 & 319 & 261 & 18 & 53 \\
\hline Lingulodinium polyedrum & 116 & 40 & 192 & 105 & 28 & - \\
\hline Protoceratium reticulatum & 409 & 443 & 423 & 183 & 6 & 30 \\
\hline Pyrophacus steinii & 10 & - & 8 & 2 & - & - \\
\hline \multicolumn{7}{|l|}{ Gymnodiniales } \\
\hline Gymnodinium catenatum & 147 & 31 & 55 & 30 & 9 & - \\
\hline Gymnodinium impudicum & 54 & 5 & 13 & - & 1 & - \\
\hline Pheopolykrikos hartmannii & 236 & 161 & 446 & 144 & 31 & 53 \\
\hline Polykrikos spp. & 20 & 7 & 8 & - & 4 & 4 \\
\hline \multicolumn{7}{|l|}{ Peridiniales } \\
\hline Diplopsalis lenticula & 50 & 41 & 13 & 11 & 6 & 3 \\
\hline Oblea acanthocysta & 13 & - & - & 1 & - & 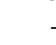 \\
\hline Preperidinium meunieri & 8 & 3 & 6 & 3 & - & - \\
\hline Protoperidinium conicum & 17 & 23 & 11 & 7 & 3 & 7 \\
\hline Protoperidinium latisinum & 17 & 16 & 17 & - & - & - \\
\hline Protoperidinium oblongum & - & 2 & 6 & 3 & - & - \\
\hline Protoperidinium pentagonum & - & - & - & 3 & - & - \\
\hline Protoperidinium sp. (spherical) & 32 & 33 & 68 & 72 & - & - \\
\hline Protoperidinium spp. & 141 & 77 & 17 & 8 & - & - \\
\hline Scrippsiella spp. & 37 & 20 & 57 & 1 & 6 & 37 \\
\hline Unidentified & 161 & 89 & 84 & 50 & 26 & 36 \\
\hline Total & 3,189 & 2,857 & 5,396 & 3,180 & 277 & 690 \\
\hline
\end{tabular}

Table 3. Distribution of dinoflagellate cysts (cells $\mathrm{g}^{-1}$ dry weight) at transect B in Yellow Sea surface sediments

\begin{tabular}{|c|c|c|c|c|c|c|c|c|c|}
\hline \multirow{2}{*}{ Species } & \multicolumn{9}{|c|}{ Stations } \\
\hline & B1 & B2 & B3 & B4 & B5 & B6 & B7 & B8 & B9 \\
\hline \multicolumn{10}{|l|}{ Gonyaulacales } \\
\hline Alexandrium spp. (ellipsoidal) & 95 & 126 & 500 & 2,408 & 2,629 & 541 & 530 & 1,876 & 287 \\
\hline Alexandrium spp. (ovoidal) & 33 & - & - & - & - & - & 15 & - & - \\
\hline Alexandrium spp. (spherical) & 243 & 154 & 468 & 375 & 542 & 109 & 65 & 185 & 15 \\
\hline Gonyaulax scrippsae & 52 & 297 & 2,858 & 6,985 & 6,650 & 5,008 & 1,684 & 1,109 & 10 \\
\hline Gonyaulax spinifera & 33 & 66 & 1,691 & 4,929 & 3,031 & 2,942 & 1,082 & 126 & 5 \\
\hline Gonyaulax spinifera complex & 10 & 22 & 64 & 375 & 335 & 96 & 116 & 50 & - \\
\hline Gonyaulax verior & 252 & 148 & 540 & 1,245 & 1,091 & 109 & 131 & 252 & 30 \\
\hline Lingulodinium polyedrum & 29 & 66 & 564 & 300 & 508 & 68 & 116 & 126 & - \\
\hline Protoceratium reticulatum & 252 & 472 & 1,977 & 1,336 & 1,465 & 1,840 & 1,488 & 433 & 25 \\
\hline Pyrophacus steinii & - & - & 16 & - & - & - & - & - & - \\
\hline \multicolumn{10}{|l|}{ Gymnodiniales } \\
\hline Gymnodinium catenatum & 29 & - & 103 & 135 & 161 & 89 & 152 & - & - \\
\hline Gymnodinium impudicum & 19 & - & 151 & 300 & 94 & 34 & - & 63 & - \\
\hline Pheopolykrikos hartmannii & 105 & 121 & 294 & 330 & 529 & 445 & 254 & 1,087 & - \\
\hline Polykrikos spp. & 10 & - & - & - & - & - & - & - & - \\
\hline \multicolumn{10}{|l|}{ Peridiniales } \\
\hline Diplopsalis lenticula & 24 & 11 & 24 & 38 & 33 & 62 & 58 & 36 & 5 \\
\hline Oblea acanthocysta & - & - & 79 & - & 20 & 82 & 15 & - & - \\
\hline Preperidinium meunieri & - & - & - & 30 & 27 & - & 15 & - & - \\
\hline Protoperidinium conicum & - & - & - & 90 & 27 & 41 & - & - & - \\
\hline Protoperidinium latisinum & 5 & - & - & - & - & - & - & - & - \\
\hline Protoperidinium oblongum & - & - & 175 & 120 & 13 & - & - & - & - \\
\hline Protoperidinium sp. (spherical) & 10 & - & 111 & 45 & 107 & - & 131 & 104 & 5 \\
\hline Protoperidinium spp. & 148 & 176 & 119 & 391 & 161 & 151 & 94 & 95 & 25 \\
\hline Scrippsiella spp. & 105 & 126 & 603 & 1,223 & 1,050 & 486 & 806 & 153 & 35 \\
\hline Unidentified & 38 & 71 & 215 & 173 & 80 & 377 & 196 & 72 & 20 \\
\hline Total & 1,492 & 1,856 & 10,552 & 20,828 & 18,553 & 12,480 & 6,948 & 5,767 & 462 \\
\hline
\end{tabular}


Table 4. Distribution of dinoflagellate cysts (cells $\mathrm{g}^{-1}$ dry weight) at transect $C$ in Yellow Sea surface sediments

\begin{tabular}{|c|c|c|c|c|c|c|c|c|c|}
\hline \multirow{2}{*}{ Species } & \multicolumn{9}{|c|}{ Stations } \\
\hline & $\mathrm{Cl}$ & $\mathrm{C} 2$ & C3 & $\mathrm{C} 4$ & C5 & C6 & $\mathrm{C7}$ & C8 & C9 \\
\hline \multicolumn{10}{|l|}{ Gonyaulacales } \\
\hline Alexandrium spp. (ellipsoidal) & 5 & 65 & 128 & 5,656 & 1,030 & 10,699 & 41 & 194 & 855 \\
\hline Alexandrium spp. (ovoidal) & - & - & 4 & - & - & - & - & - & - \\
\hline Alexandrium spp. (spherical) & 23 & 70 & 71 & 463 & 9 & 726 & - & - & 70 \\
\hline Gonyaulax scrippsae & 14 & 135 & 287 & 4,567 & 5,716 & 1,869 & 2,309 & 1,246 & 495 \\
\hline Gonyaulax spinifera & - & 19 & 190 & 1,228 & 2,272 & 1,243 & 662 & 315 & 102 \\
\hline Gonyaulax spinifera complex & - & 5 & 26 & 88 & 160 & 60 & 55 & 27 & 27 \\
\hline Gonyaulax verior & 5 & 47 & 31 & 2,714 & 293 & 1,760 & - & 60 & 118 \\
\hline Lingulodinium polyedrum & - & 33 & 9 & 250 & 80 & 159 & 62 & 20 & 5 \\
\hline Protoceratium reticulatum & - & 135 & 379 & 750 & 257 & 577 & 1,082 & 395 & 543 \\
\hline Pyrophacus steinii & - & 5 & 4 & - & - & 40 & - & - & - \\
\hline \multicolumn{10}{|l|}{ Gymnodiniales } \\
\hline Gymnodinium catenatum & - & 9 & 4 & 15 & 53 & 60 & 14 & 13 & 5 \\
\hline Gymnodinium impudicum & 9 & 5 & 35 & - & - & - & - & - & - \\
\hline Pheopolykrikos hartmannii & 14 & 28 & 13 & 338 & 44 & 328 & 248 & 167 & 317 \\
\hline Polykrikos spp. & 6 & - & - & - & - & - & - & - & - \\
\hline \multicolumn{10}{|l|}{ Peridiniales } \\
\hline Diplopsalis lenticula & - & 9 & 18 & 15 & 107 & 119 & 138 & 54 & 5 \\
\hline Oblea acanthocysta & - & - & - & - & 27 & - & 7 & - & 5 \\
\hline Preperidinium meunieri & 5 & - & - & - & - & 20 & 28 & - & 5 \\
\hline Protoperidinium conicum & - & 9 & 18 & 22 & - & 10 & - & 13 & - \\
\hline Protoperidinium oblongum & 5 & 5 & - & 29 & 18 & 20 & 14 & - & - \\
\hline Protoperidinium sp. (spherical) & - & 9 & 9 & 74 & 44 & 159 & 28 & 13 & 5 \\
\hline Protoperidinium spp. & 23 & 103 & 67 & 74 & 18 & 70 & 117 & 127 & 70 \\
\hline Scrippsiella spp. & - & 9 & 93 & 699 & 1,784 & 696 & 283 & 87 & 70 \\
\hline Unidentified & 5 & 14 & 49 & 110 & 195 & 259 & 104 & 94 & 54 \\
\hline Total & 114 & 714 & 1,435 & 17,092 & 12,107 & 18,874 & 5,192 & 2,825 & 2,751 \\
\hline
\end{tabular}

Table 5. Distribution of dinoflagellate cysts (cells $\mathrm{g}^{-1}$ dry weight) at transect D in Yellow Sea surface sediments

\begin{tabular}{|c|c|c|c|c|c|c|c|c|c|}
\hline \multirow{2}{*}{ Species } & \multicolumn{9}{|c|}{ Stations } \\
\hline & D1 & D2 & D3 & D4 & D5 & D6 & D7 & D8 & D9 \\
\hline \multicolumn{10}{|l|}{ Gonyaulacales } \\
\hline Alexandrium spp. (ellipsoidal) & - & - & 178 & 300 & 398 & 1,138 & 199 & 193 & 109 \\
\hline Alexandrium spp. (ovoidal) & - & - & 7 & 19 & - & - & 19 & 5 & 6 \\
\hline Alexandrium spp. (spherical) & 110 & 10 & 36 & 138 & 509 & 206 & 12 & 27 & 19 \\
\hline Gonyaulax scrippsae & 46 & 45 & 721 & 2,063 & 1,305 & 2,872 & 1,207 & 529 & 410 \\
\hline Gonyaulax spinifera & 37 & 30 & 336 & 544 & 731 & 845 & 224 & 182 & 237 \\
\hline Gonyaulax spinifera complex & 18 & 15 & - & 50 & 56 & 29 & 37 & 16 & 6 \\
\hline Gonyaulax verior & 83 & - & 50 & 169 & 93 & 51 & 87 & 96 & 26 \\
\hline Lingulodinium polyedrum & 18 & - & 21 & 156 & 46 & 73 & - & 16 & 6 \\
\hline Protoceratium reticulatum & - & 30 & 178 & 288 & 185 & 81 & 100 & 96 & 103 \\
\hline Pyrophacus steinii & - & - & 7 & - & - & - & 25 & 5 & 6 \\
\hline \multicolumn{10}{|l|}{ Gymnodiniales } \\
\hline Gymnodinium catenatum & 18 & - & 29 & - & 130 & 73 & - & 11 & 6 \\
\hline Gymnodinium impudicum & - & 10 & 7 & 25 & 28 & 29 & 19 & 16 & 26 \\
\hline Pheopolykrikos hartmannii & 120 & 5 & 79 & 269 & 185 & 235 & 75 & 59 & 26 \\
\hline Polykrikos spp. & 119 & 5 & - & - & 9 & - & 6 & 5 & 6 \\
\hline \multicolumn{10}{|l|}{ Peridiniales } \\
\hline Diplopsalis lenticula & 9 & - & 7 & 6 & - & 44 & 31 & 11 & 32 \\
\hline Oblea acanthocysta & - & - & 14 & - & 19 & 55 & - & - & - \\
\hline Protoperidinium conicum & 9 & - & 7 & 13 & 9 & 22 & 19 & 21 & - \\
\hline Protoperidinium oblongum & - & - & - & - & 9 & - & 12 & - & - \\
\hline Protoperidinium sp. (spherical) & 9 & 20 & 7 & 13 & 65 & 29 & 31 & 16 & - \\
\hline Protoperidinium spp. & 82 & 25 & 28 & 76 & 93 & 22 & 56 & 80 & 12 \\
\hline Scrippsiella spp. & 28 & 5 & 71 & 125 & 111 & 125 & 37 & 21 & 96 \\
\hline Unidentified & 9 & 10 & 43 & 112 & 55 & 81 & 12 & - & 6 \\
\hline Total & 715 & 210 & 1,826 & 4,366 & 4,036 & 5,977 & 2,208 & 1,405 & 1,138 \\
\hline
\end{tabular}



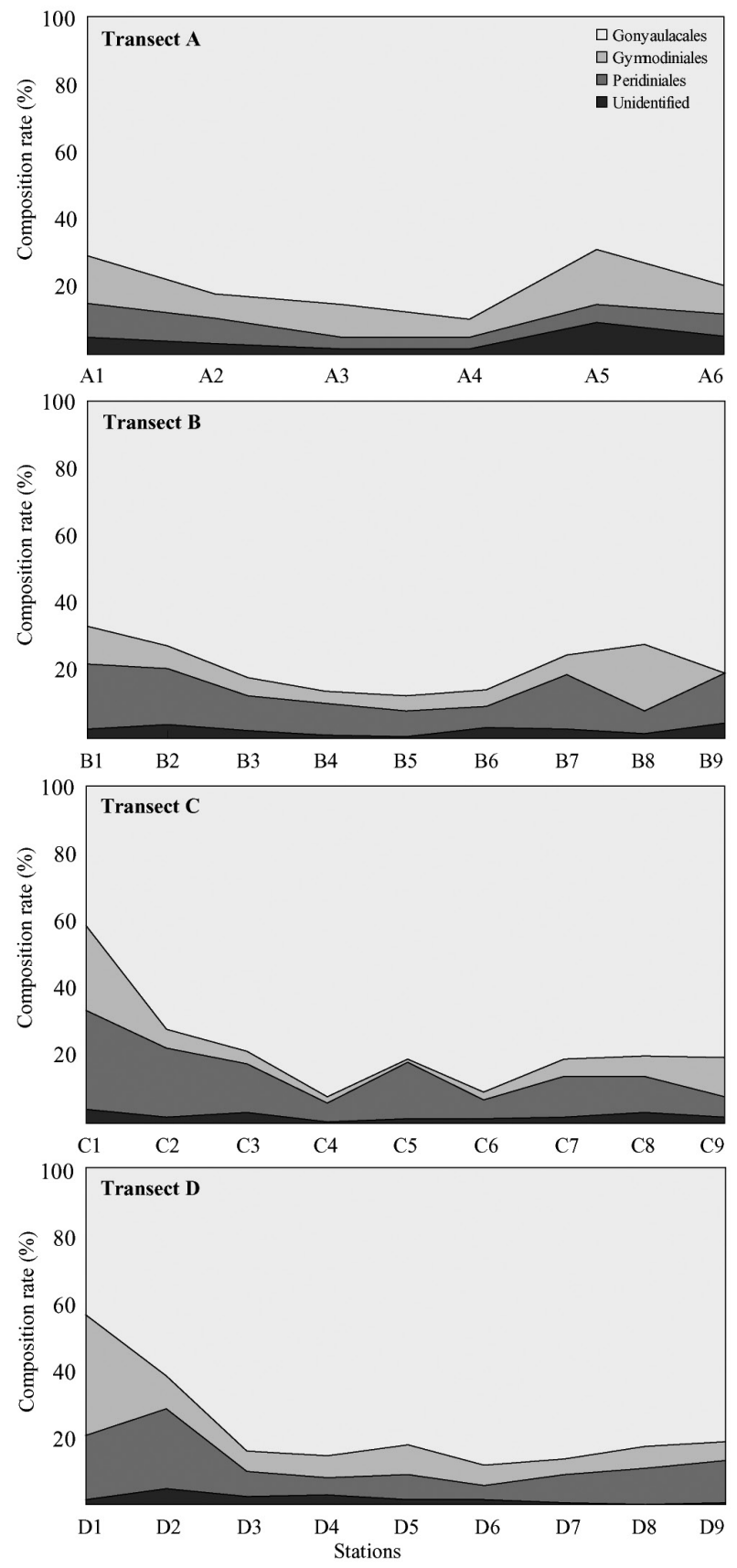

Fig. 2. Longitudinal change in the relative abundance of dinoflagellate cysts in each transect categorized by a motile cell-based classification in Yellow Sea surface sediments.

dal type, 95-2,629 cells $\mathrm{g}^{-1}$ ), and Protoceratium reticulatum (25-1,977 cells $\left.\mathrm{g}^{-1}\right)$.

Twenty-three types of cysts were encountered at transect C, which was between transect B and the southernmost transect D (Table 4, Fig. 1). Cyst concentrations were high in the central areas (stations C4-C6, 12,107-18,874 cells $\mathrm{g}^{-1}$ ) and decreased sharply toward the marginal areas of both the Chinese and Korean coasts. The lowest density among all sediment samples analyzed was recorded at station $\mathrm{C} 1$ on the Chinese coast (114 cells $\mathrm{g}^{-1}$ ).

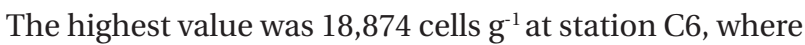
Alexandrium spp. (ellipsoidal type, 10,699 cells $\mathrm{g}^{-1}$ ) contributed $>50 \%$ to the total concentration. The variation in the number of ellipsoidal Alexandrium cysts accounted for the substantial fluctuations in total cyst concentrations. For example, the relatively low cyst concentration at station C5 was accompanied by a substantially low number of ellipsoidal Alexandrium cysts.

Transect D was the southernmost transect located off Jeju Island, and 22 cyst types were identified (Table 5, Fig. 1). The offshore stations (stations D4-D6, 4,036-5,977 cells $\mathrm{g}^{-1}$ ) showed much higher cyst concentrations than did the nearshore stations (Fig. 1). The most dominant species was Gonyaulax scrippsae (45-2,872 cells $\left.\mathrm{g}^{-1}\right)$.

Cyst densities were generally highest near the offshore center of the Yellow Sea and gradually decreased towards both the Chinese and Korean coasts within each transect (Fig. 1). The middle transects B and C showed higher concentrations than did the northern transect $\mathrm{A}$ and the southern transect D. However, the trend of a gradual decrease towards the higher and lower latitudes was less prominent than that towards both nearshore directions. Cyst concentrations on the Chinese coast were relatively lower than those on the Korean coast.

Dinoflagellate cysts belonging to the Gonyaulacales generally comprised over $50 \%$ of all cysts collected, but two exceptions of an abrupt proportional decrease in Gonyaulacales at stations $\mathrm{Cl}$ and $\mathrm{D} 1$ on the Chinese coast were noteworthy (Fig. 2). The proportional density of the Protoperidiniales tended to gradually increase toward the Chinese and Korean coasts, whereas total cyst concentrations decreased dramatically.

\section{DISCUSSION}

The 33 sediment samples surveyed in this study provided dinoflagellate cyst records from nearly the entire Yellow Sea continental shelf. Cho and Matsuoka (2001) investigated the cyst spatial distributions in the East China and Yellow Seas, but their study areas covered only parts of the Yellow Sea; thus, they provided limited information on dinoflagellate cyst biogeography. The sampling stations surveyed in our study covered wide areas along four latitudinal transacts that connected the Chinese and Korean coasts, of which the northernmost 
transect was level with the Shandong Peninsula and the southernmost was level with Jeju Island.

Cyst concentrations were generally markedly elevated around the center of the Yellow Sea and gradually decreased in all four outward directions. This result was congruent with Cho and Matsuoka (2001) who investigated the spatial distributions of cysts in the East China and Yellow Seas and noted unusually high cyst concentrations in the offshore center of the Yellow Sea. Our result of high offshore cyst concentrations in the Yellow Sea were also comparable to those of Cho et al. (2003) who reported that the number of cysts at offshore stations was approximately four times higher than that at inshore stations in the southern Korea Sea. This tendency toward increased cyst abundance in an offshore direction has also been well documented in previous studies (e.g., White and Lewis 1982, Dale et al. 2002). The total number of cysts recorded around the offshore center of the Yellow Sea was much higher than that of previous studies from the Korean coast (Cho and Matsuoka 2001, Park and Yoon 2003, Park et al. 2004).

The distribution of dinoflagellate cysts is governed

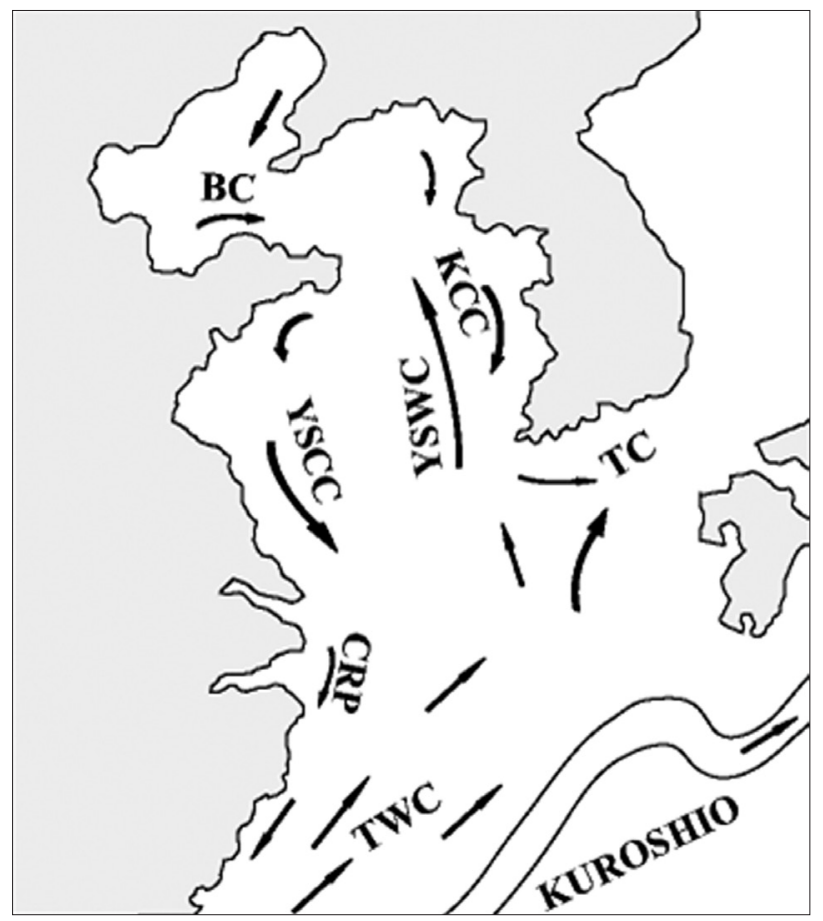

Fig. 3. The circulation features in the Yellow Sea, adopted from $\mathrm{Su}$ (1998). The features identified are the Bohai Coastal Current (BC), the Yellow Sea Coastal Current (YSCC), the Changjiang River Plume (CRP), the Taiwan Warm Current (TWC), the Tsushima Current (TC), the Yellow Sea Warm Current (YSWC), and the Korean Coastal Current (KCC). not only by environmental factors such as sediment particle size, sedimentation rate, and hydrographic and geographical features but also by biological factors (Dale 1976, White and Lewis 1982, Turgeon et al. 1990). Cysts behave like fine-grained sedimentary particles and move and concentrate along hydrodynamic systems.

The general hydrographic features of the Yellow Sea are characterized by the northward inflow of the Yellow Sea Warm Current and the subsequent southward flow along the Chinese and Korean coasts (i.e., the Yellow Sea Coastal Current and the Korean Coastal Current, Fig. 3). These coastal currents are compensated for by the northward flow of the Yellow Sea cold bottom water along the Yellow Sea trough, which forms a large cyclonic (counterclockwise) eddy in the central part of the Yellow Sea (Su 1998, Shi et al. 2004). Thus, surface sediment distributions are under the direct influence of the centrifugal force of this current movement, and the largest fine-grained muddy deposits are located in the offshore central Yellow Sea (Park and Khim 1992, Uehara and Saito 2003). Shi et al. (2004) demonstrated that the net transport direction of sediments in the Yellow Sea is toward the centrally located fine-grained sediment deposits. This sediment transport pattern is also consistent with several tracers of sediment sources such as the distribution of total suspended matter concentrations, the $\delta^{13} \mathrm{C}$ value of particulate organic carbon, values of polycyclic aromatic hydrocarbons (Shi et al. 2004), and various geochemical elements (Kim et al. 1998). These sedimentary materials originated and were dispersed from the old- and present-day Huang He (Yellow River) system (Alexander et al. 1991, Park and Khim 1992, Shi et al. 2004).

Our results showing concentric high-density cyst concentrations in the Yellow Sea were also congruent with these sedimentary properties, which were strongly correlated with water depth and the current circulatory system. Thus, high cyst concentrations in the offshore central Yellow Sea can be attributed to the prevailing Yellow Sea circulation associated with the transportation and deposition of fine-grained sediments. A tendency for an increase in the relative abundance of cysts along a deepsea gradient may be largely influenced by larger scale offshore transport of neritic and estuarine cysts to deeper depositional sites (Dale et al. 2002).

Other than the underlying possibility of an exogenous origin for most benthic cysts in the central Yellow Sea, there are also possibilities for endogenous origins, e.g., offshore migration of neritic dinoflagellate bloom populations or vertical sinking of in situ bloom populations from the overlying water column after sexual reproduc- 
tion (Tyler et al. 1982). An endogenous origin is actually supported by a spring phytoplankton bloom in the central Yellow Sea (Hyun and Kim 2003).

Ellipsoidal Alexandrium cysts composed of A. acatenella, A. catenella, A. fundyense, A. tamarense, and A. tamiyavanichii (Yoshida et al. 2003) were the most ubiquitous taxa recorded in the Yellow Sea. These species possibly produce paralytic shellfish poisoning (PSP) toxins and frequently occur in the coastal waters of China and Korea (Zhou et al. 1999, Kim et al. 2002). The geographic range of ellipsoidal Alexandrium cysts in the Yellow Sea was extensive with high concentric offshore accumulations, the values of which are comparable to those of other coastal areas (for references, see Cho and Matsuoka 2001). Over the last two decades, southern coastal areas of Korea have suffered from annul PSP incidents, accompanied by great economic losses caused by a ban on shellfish harvesting (Kim 1997). Jeon et al. (1988) reported actual shellfish contaminations by PSP on the western coast of Korea. Kim et al. (2002) established several PSP-causing A. tamarense isolates from sediment cysts from the Yellow Sea, and Kim and Kim (2004) showed extreme homogeneity of the ribosomal DNA sequence data to other isolates around Korea and other countries. Therefore, the high offshore reservoir of benthic cysts may play a critical role providing inoculum sites for rapid, large Alexandrium blooms in the overlying water column under favorable conditions (White and Lewis 1982, Turgeon et al. 1990). A great potential for future PSP outbreaks exists in coastal areas around the Yellow Sea, and this necessitates periodic and persistent $\mathrm{HAB}$ monitoring.

Marine environmental conditions can be estimated by changes in total cyst productivity and proportional changes in a particular taxon (Dale et al. 1999, 2002, Matsuoka 1999). For example, a high relative abundance of heterotrophic protoperidinioid cysts occurs in nutrientenriched areas such as in upwellings or eutrophicated coastal areas (Dale et al. 2002). The proportion of heterotrophic cysts belonging to the Protoperidiniales was lowest in the central Yellow Sea and gradually increased toward the Chinese and Korean coasts along with a dramatic decrease in total cyst concentrations. The significant proportional increase in protoperidinioid cysts towards the Chinese coast is noteworthy and may imply that environmental conditions at these coastal areas differ from conditions at other areas. However, the proportions of heterotrophic protoperidinioid cysts on the Chinese and Korean coasts of the Yellow Sea are lower than other coastal areas (e.g., Matsuoka et al. 2003, Shin et al. 2010). However, this interpretation may be arbitrary due to transport and dispersal of sedimentary materials containing microflora by the prevailing hydrographic system mentioned above.

Among 2,000 extant dinoflagellate species, approximately $5 \%$ are known to have a corresponding cyst stage in their life cycle (Matsuoka and Fukuyo 2003). Cyst morphologies of many notorious HAB species such as Cochlodinium polykrikoides, Karenia brevis, and K. mikimotoi remain unknown and this prohibits their geographical mapping, which would be useful for efficient $\mathrm{HAB}$ prediction and control. Recent accumulation of molecular sequence data from $\mathrm{HAB}$ species and advances in molecular techniques have enabled us to design sensitive and accurate oligonucleotide probes to detect and quantify HAB species of interest (Kim et al. 2004 and references therein). Various molecular detection assays have been applied to detect dinoflagellate cysts in marine sediments (e.g., Godhe et al. 2002, Saito et al. 2002). Therefore, it may be possible to draw biogeographical maps of previously unidentified taxa as long as appropriate DNA probes are available. Our ongoing study focuses on the application of such up-to-date molecular tools to sediment samples from the Yellow Sea for genetic profiling of $\mathrm{HAB}$ species for which geographical mapping is impossible.

\section{ACKNOWLEDGEMENTS}

This work was supported by "The Yellow Sea Environment Cooperative Research between Korea and China” of the NFRDI in Korea. We thank Dr. Seung Heo of West Sea Fisheries Research Institute of NFRDI for his help for the sediment sampling.

\section{REFERENCES}

Alexander, C. R., DeMaster, D. J. \& Nittrouer, C. A. 1991. Sediment accumulation in a modern epicontinental-shelf setting: the Yellow Sea. Mar. Geol. 98:51-72.

Cho, H. -J., Kim, C. -H., Moon, C. -H. \& Matsuoka, K. 2003. Dinoflagellate cysts in recent sediments from the southern coastal waters of Korea. Bot. Mar. 46:332-337.

Cho, H. -J. \& Matsuoka, K. 2001. Distribution of dinoflagellate cysts in surface sediments from the Yellow Sea and East China Sea. Mar. Micropaleontol. 42:103-123.

Cho, H. -J., Matsuoka, K., Lee, J. -B. \& Moon, C. -H. 2001. Dinoflagellate cyst assemblages in the surface sediments from the northwestern East China Sea. J. Fish. Sci. Tech- 
nol. 4:120-129.

Dale, B. 1976. Cyst formation, sedimentation, and preservation: factors affecting dinoflagellate assemblages in recent sediments from Trondheimsfjord, Norway. Rev. Palaeobot. Palynol. 22:39-60.

Dale, B., Dale, A. L. \& Jansen, J. H. F. 2002. Dinoflagellate cysts as environmental indicators in surface sediments from the Congo deep-sea fan and adjacent regions. Palaeogeogr. Palaeoclimatol. Palaeoecol. 185:309-338.

Dale, B., Thorsen, T. A. \& Fjellså, A. 1999. Dinoflagellate cysts as indicators of cultural eutrophication in the Oslofjord, Norway. Estuar. Coast. Shelf Sci. 48:371-382.

Godhe, A., Rehnstam-Holm, A. -S., Karunasagar, I. \& Karunasagar, I. 2002. PCR detection of dinoflagellate cysts in field sediment samples from tropic and temperate environments. Harmful Algae 1:361-373.

Hyun, J. -H. \& Kim, K. -H. 2003. Bacterial abundance and production during the unique spring phytoplankton bloom in the central Yellow Sea. Mar. Ecol. Prog. Ser. 252:77-88.

Jeon, J. -K., Yi, S. K. \& Huh, H. T. 1988. Paralytic shellfish poisoning of bivalves in the Korean waters. J. Oceanol. Soc. Korea 23:123-129 (in Korean).

Jin, J. H. \& Chough, S. K. 1998. Partitioning of transgressive deposits in the southeastern Yellow Sea: a sequence stratigraphic interpretation. Mar. Geol. 149:79-92.

Kim, C. -H., Park, G. -H. \& Kim, K. -Y. 2004. Sensitive, accurate PCR assays for detecting harmful dinoflagellate Cochlodinium polykrikoides using a specific oligonucleotide primer set. J. Fish. Sci. Technol. 7:122-129.

Kim, G., Yang, H. -S. \& Kodama, Y. 1998. Distributions of transition elements in the surface sediments of the Yellow Sea. Cont. Shelf Res. 18:1531-1542.

Kim, H. G. 1997. Recent harmful algal blooms and mitigation strategies in Korea. Ocean Res. 19:185-192.

Kim, K. -Y. \& Kim, C. -H. 2004. A molecular phylogenetic study on Korean Alexandrium catenella and A. tamarense isolates (Dinophyceae) based on the partial LSU rDNA sequence data. J. Korean Soc. Oceanogr. 39:163171.

Kim, K. -Y., Yoshida, M., Fukuyo, Y. \& Kim, C. -H. 2002. Morphological observation of Alexandrium tamarense (Lebour) Balech, A. catenella (Whedon et Kofoid) Balech and one related morphotype (Dinophyceae) in Korea. Algae 17:11-19.

Matsuoka, K. 1999. Eutrophication process recorded in dinoflagellate cyst assemblages: a case of Yokohama Port, Tokyo Bay, Japan. Sci. Total Environ. 231:17-35.

Matsuoka, K. \& Fukuyo, Y. 2000. Technical guide for modern dinoflagellate cyst study. WESTPAC-HAB/WESTPAC/
IOC, Tokyo, $77 \mathrm{pp}$.

Matsuoka, K. \& Fukuyo, Y. 2003. Taxonomy of cysts. In Hallegraeff, G. M., Anderson, D. M. \& Cembella, A. D. (Eds.) Manual on Harmful Marine Microalgae. UNESCO Publishing, Paris, pp. 563-592.

Matsuoka, K., Joyce, L. B., Kotani, Y. \& Matsuyama, Y. 2003. Modern dinoflagellate cysts in hypertrophic coastal waters of Tokyo Bay, Japan. J. Plankton Res. 25:1461-1470.

Park, G. -H., Kim, K. -Y., Kim, C. -H. \& Kim, H. G. 2004. Spatio-temporal distribution of dinoflagellate resting cysts at the Saemangeum area. J. Korean Fish. Soc. 37:202-208 (in Korean).

Park, J. S. \& Yoon, Y. H. 2003. Marine environmental characteristics by distribution of dinoflagellates cysts in the southwestern coastal waters of Korea. 1. Spatio-temporal distribution of dinoflagellates cysts in Gamak Bay. J. Korean Fish. Soc. 36:151-156 (in Korean).

Park, Y. A. \& Khim, B. K. 1992. Origin and dispersal of recent clay minerals in the Yellow Sea. Mar. Geol. 104:205-213.

Pfiester, L. A. \& Anderson, D. M. 1987. Dinoflagellate reproduction. In Taylor, F. J. R. (Ed.) The Biology of Dinoflagellates. Blackwell Scientific Publications, Oxford, pp. 611-648.

Qi, Y. -Z., Hong, Y., Zheng, L., Kulis, D. M. \& Anderson, D. M. 1996. Dinoflagellate cysts from recent marine sediments of the South and East China Seas. Asian Mar. Biol. 13:87-103.

Saito, K., Drgon, T., Robledo, J. A. F., Krupatkina, D. N. \& Vasta, G. R. 2002. Characterization of the rRNA locus of Pfiesteria piscicida and development of standard and quantitative PCR-based detection assays targeted to the nontranscribed spacer. Appl. Environ. Microbiol. 68:5394-5407.

Shi, X., Chen, Z., Cheng, Z., Cai, D., Bu, W., Wang, K., Wei, J. \& Yi, H. -I. 2004. Transportation and deposition of modern sediments in the southern Yellow Sea. J. Korean Soc. Oceanogr. 39:57-71.

Shin, H. H., Mizushima, K., Oh, S. J., Park, J. S., Noh, I. H., Iwataki, M., Matsuoka, K. \& Yoon, Y. H. 2010. Reconstruction of historical nutrient levels in Korean and Japanese coastal areas based on dinoflagellate cyst assemblages. Mar. Pollut. Bull. 60:1243-1258.

$\mathrm{Su}$, J. 1998. Circulation dynamics of the China Seas north of 18N. In Robinson, A. R. \& Brink, K. H. (Eds.) The Sea, Vol. 11: The Global Coastal Ocean, Regional Studies and Syntheses. Wiley, New York, pp. 483-505.

Turgeon, J., Cembella, A. D., Therriault, J. -C. \& Beland, P. 1990. Spatial distribution of resting cysts of Alexandrium spp. in sediments of the lower St. Lawrence estuary and the Gaspé coast (eastern Canada). In Granéli, F, 
Sundström, B., Edler, L. \& Anderson, D. M. (Eds.) Toxic Marine Phytoplankton. Elsevier, New York, pp. 238-243.

Tyler, M. A., Coats, D. W. \& Anderson, D. M. 1982. Encystment in a dynamic environment: deposition of dinoflagellate cysts by a frontal convergence. Mar. Ecol. Prog. Ser. 7:163-178.

Uehara, K. \& Saito, Y. 2003. Late quaternary evolution of the Yellow/East China Sea tidal regime and its impacts on sediments dispersal and seafloor morphology. Sediment. Geol. 162:25-38.
White, A. W. \& Lewis, C. M. 1982. Resting cysts of the toxic, red tide dinoflagellate Gonyaulax excavata in Bay of Fundy sediments. Can. J. Fish. Aquat. Sci. 39:1185-1194. Yoshida, M., Mizushima, K. \& Matsuoka, K. 2003. Alexandrium acatenella (Gonyaulacales: Dinophyceae): morphological characteristics of vegetative cell and resting cyst. Plankton Biol. Ecol. 50:61-64.

Zhou, M., Li, J., Luckas, B., Yu, R., Yan, T., Hummert, C. \& Kastrup, S. 1999. A recent shellfish toxin investigation in China. Mar. Pollut. Bull. 39:331-334. 